\title{
Almanca Dilbilgisi Derslerinde Ölçme ve Değerlendirme
}

\author{
Fatma Karaman (i), Muğla \\ doi https://dx.doi.org/10.37583/diyalog. 759436
}

\begin{abstract}
$\ddot{O} z$
Ölçme ve değerlendirme birçok alanda olduğu gibi yabancı dil öğretiminde de büyük bir öneme sahiptir. Ölçme işlemi, öğrenciye not vermenin yanı sıra öğretim sürecinin, programın, yöntemin etkililiği gibi birçok amaç için de yapılmaktadır. Öğretim sürecinin etkililiğini belirlemek için ise amaca hizmet eden ölçme araçlarının hazırlanması önemli bir unsurdur. Almanca dilbilgisi dersinin ölçme sürecinde genellikle boşluk doldurma, eşleştirme gibi ölçme teknikleri kullanılmaktadır. Ancak bu özellikteki ölçme araçları, dilin biçimsel yönünün ölçülmesini sağlarken; dilin kullanım yönünü ölçmede yetersiz kalmaktadır. Bu bağlamda bu çalışmanın amacı Almanca dilbilgisi derslerinde etkili bir ölçme ve değerlendirme yapabilmek için kullanılan ölçme araçlarının hangi özelliklere sahip olması gerektiği, ölçme aracı hazırlarken soruların nitelikleri, yapısı, ölçme aracının amaca hizmet etmesi için hangi özelliklere sahip olması gerektiğine ilişkin önerilerde bulunmaktır. Çalışmanın sonucunda ölçme ve değerlendirme sürecine işlevsellik kazandırmak amacıyla alternatif ölçme araçlarının kullanılması gerektiği vurgulanarak Almanca dilbilgisi dersinin ölçme ve değerlendirme aşamasında kullanılabilecek alternatif ölçme ve değerlendirme tekniklerine ilişkin önerilerde bulunulmuştur.
\end{abstract}

Anahtar Sözcükler: Yabancı dil öğretimi, Almanca dilbilgisi, İletişimsel yaklaşım, Ölçme ve değerlendirme, Ölçme aracı

\section{Abstract}

\section{Assessment and Evaluation in German Grammar Courses}

Assessment and evaluation are of great importance in foreign language teaching as in many fields. The following evaluation process is carried out for many purposes, such as the effectiveness of the teaching process, program and method, as well as, giving the student a grade. In order to determine the effectiveness of the teaching process, the preparation of evaluation tools that will be used is an important factor. In the evaluation process of the German grammar course, the evaluation tools consist of "gapfilling" and "matching-type" measuring techniques are generally used. However, while evaluation tools in this feature allow to measure the formal direction of the language, it is inadequate to measure the level of the use of language. In this context, the aim of this study is to make suggestions about the features of the evaluation tools which used to make an effective assessment consequently evaluation in German grammar lessons, the characteristics of the items, the structure of the items while preparing the evaluation tool, and what features the evaluation tool should have been organized for the purpose. As a result of the study, it is emphasized that alternative evaluation tools should be used in order to add functionality to the assessment and evaluation process. Suggestions are made regarding alternative assessment, and evaluation techniques that can be used in German grammar courses. 
Keywords: Foreign language teaching, German grammar, Communicative approach, Assessment and evaluation, Assessment tool

\section{EXTENDED ABSTRACT}

However, while evaluation tools in productional feature allow to measure the formal direction of the language, it is inadequate in measuring the direction of the use of language. In this context, the aim of this study is to make suggestions about the features of the evaluation tools which are used to make an effective assessment and evaluation in German grammar lessons, the characteristics of the items, the structure of the items while preparing the evaluation tool, and what features the evaluation tool should have been prepared for the purpose.

In education, measurement and evaluation can be done in two ways, using traditional and alternative techniques. While "correct, wrong, matching, filling in questions, short and long answer written polls" are evaluated as traditional measurement and evaluation techniques; "performance evaluation, product selection file (portfolio), concept maps, project, drama, interview, written reports, demonstration, poster, group or peer evaluation, self-evaluation, word association tests" are classified as alternative measurement and evaluation techniques (Meb 2007). Alternative measurement and evaluation techniques are not only result-oriented as in traditional measurement and evaluation;

it is more efficient in terms of evaluating students' learning processes by focusing on students. Alternative measurement and evaluation techniques are briefly described below.

In performance evaluation, the student uses high-level mental skills such as analysis, reasoning, criticism and synthesis to produce. Assessment can be made on the product of the student, by taking into account certain criteria.

Product selection file (portfolio); this is the file that shows every performance of the student during the teaching process for a period, the stages that the student has passed through the teaching process from the beginning and shows all the work that done by the student (Dağl1 2014: 39). With this technique, the teacher is not only looking at a single examination paper, as in the traditional measurement and evaluation techniques of the development of each student throughout the semester but also; by evaluating more than one product during the semester, he can make a judgment about the student.

Concept map; It is a technique that provides a link between concepts by classifying information and thoughts about a basic or upper concept (Altınok / Açıkgöz 2006: 22). In this technique, learning deficiencies can be detected by classifying among the related topics.

Project technique; It is the students' extensive research on a topic or problem, both individually and in groups, to produce various products (Sünbül 2011: 175). In this technique, students are encouraged to continue learning in out-of-school settings by evaluating their work in both school and out-of-school settings.

Peer assessment technique is that students evaluate each other's works and products (Dağl1 2014: 57). In this technique, the responsibility of learning and assessment is given to the other students in the class, and the studies in classroom that are successful or not at the expected level are examined and evaluated by other students apart from the teacher.

Validity of measurement tools which created with traditional techniques such as "filling gaps, completing missing sentences, true and false" in German grammar course; will be low as it fails to measure the knowledge and skills that need to be measured. In addition to this, a measurement at the level of knowledge is made with traditional measurement techniques. In 
order to measure the target acquisitions in grammar as a whole with language skills, productionbased techniques that allow students to measure products created by using grammar topics should be preferred. In this context, suggestions for using alternative assessment and evaluation techniques by adapting them to German grammar lessons are explained below.

Adjectives in German is structurally different from adjectives in native or English. Concept maps can be used as a measurement tool in order to achieve the purpose of measuring all the different states of relational adjectives in a connected way. Performance assessment technique can be used to measure, whether adjectives in German are used functionally by students or not? Using visuals in the measurement tool developed here, students may be asked to depict an object they wish to own or someone they admire.

Another alternative measurement and evaluation technique is written reports. This technique can be preferred especially for measuring the subject of time. For example, the semantic closeness between "man-Konstruktion" (passive subject) and "werden + Partizip Perfekt" (passive structure) can be revealed by using word association tests technique. Therefore, with this technique, it is measured whether the student knows whether different structures are used in the same or near meaning. In addition to this, since the correlation is made in this technique, not only the measurement and evaluation process, but also the learning process is supported. Performance evaluation technique can be used to measure the wish and condition mode. In this technique, as stated above, story, composition and poetry writing tasks can be given to students. Poetry, which is a literary genre, can be preferred according to the function of the wish and condition mode. In this context, students may be asked to write a poem in which they express their demands for a person or object they yearn for. In this way, the level of use of the wish mode, both formally and functionally, is measured.

The measurement and evaluation phase, which gives information about this process as well as the planning and implementation of the teaching process, is an important stage affecting the teaching. In this study, it is emphasized that an evaluation should not be made only by looking at the scores of the students and in the teaching process. It is emphasized that performing measurement and evaluation with alternative measurement and evaluation techniques in which students can produce the products they perform by using more than one mental skills will contribute to both the reliable measurement and evaluation and the teaching. Useful, fictional, and original texts, dialogues, songs, fables, stories, newspaper ads, recipes, invitations, user guides, advertisement texts can be arranged in the form of materials in alternative measurement and evaluation techniques while creating measurement tools in German grammar lessons. In addition, concept maps, performance evaluation, product selection file, project, drama, interview, written reports, demonstrations, teacher observations, student selfevaluations should be included in the process as alternative measurement and evaluation techniques. 


\section{Giriş}

Ölçme ve değerlendirme; öğretim programlarında yer alan kazanım, içerik, öğrenme ve öğretme sürecinden sonra öğretim programlarının dördüncü ve son öğesini oluşturmaktadır. Genel olarak ölçme ve değerlendirme işlemi; uygulanan programın, kullanılan yöntemin, etkinliklerin, kazanımların ulaşılma düzeyini, bilgi ve becerileri ölçmek, ihtiyaç analizi yapmak kısacası öğretim süreci hakkında bilgi almak amacıyla yapılmaktadır. Dolayısıyla ölçme ve değerlendirme öğretim programlarının diğer bütün öğelerini de etkileyen dinamik bir aşamadır.

Eğitimin diğer alanlarında da ölçme araçları büyük bir öneme sahipken; bu önem yabancı dil öğretiminde daha da artmaktadır. Çünkü ölçme ve değerlendirme sürecinde kullanılan ölçme araçlarına bağlı olarak birçok konuda değerlendirme ve yönlendirme yapılmaktadır. Dolayısıyla öğretim sürecinin etkililiğini belirlemek için amaca hizmet eden ölçme araçlarının hazırlanması önemli bir unsurdur. Ölçme ve değerlendirme işlemi öğretim sürecinde belirlenen kazanımlara hangi ölçüde ulaşıldığının ve eksikliklerin neler olduğunun tespit edilmesine yönelik yapılmaktadır.

Bilindiği gibi günümüzde yabancı dil öğretiminde geleneksel yöntemler yerine alternatif yöntemlerin kullanılması tercih edilmektedir. Yabancı dil öğretimindeki yöntem arayışları ölçme ve değerlendirmede de yöntem arayışlarını zorunlu kılmıştır. Kullanılan yöntemlerin farklılık göstermesi ölçme ve değerlendirmede kullanılan ölçme araçlarında da iyileştirme ve geliştirme yapılmasını gerektirmektedir. Ancak ölçme sürecinde kullanılan ölçme araçları incelendiğinde genel olarak öğretmenler tarafindan oluşturulan yabancı dil ölçme araçlarında çoktan seçmeli, eşleştirme, boşluk doldurma gibi soru türlerinin kullanıldığı anlaşılmaktadır. $\mathrm{Bu}$ soru türleri ise zihinsel süreç becerilerine ihtiyaç duyulmadan ezbere dayalı olarak öğrenciler tarafından cevaplanabilmektedir. Ezbere dayalı soru türleri ise davranışçı öğretim yaklaşımına dayanmaktadır. Görüldüğ̈̈ gibi yabancı dil öğretiminde yapılandırmacı öğretim yaklaşımı benimsenmekteyken; ölçme sürecinde ölçme aracı oluştururken davranışçı yaklaşımın özelliklerine göre bir tasarı yapılmaktadır. Bu durum ise yabancı dil öğretiminde farklı bir sorun olarak karşımıza çıkmaktadır. Çünkü doğru ve güvenilir ölçme işlemi, hazırlanan ölçme araçlarının niteliğine bağlıdır. Amaca hizmet etmeyen bir ölçme aracı öğretim sürecine ilişkin güvenilir bilgiler veremeyeceği için doğru değerlendirmelerin yapılması da mümkün olmamaktadır. Genel anlamda yabancı dil ölçme sürecinde görülen bu durum, özel anlamda Almanca dilbilgisinin ölçülmesinde de ortaya çıkmaktadır. Bilindiği gibi geleneksel dilbilgisi öğretiminde dilin soyut kavramlarının öğrencilere aktarımı söz konusudur. Geleneksel dilbilgisi öğretimine bağlı olarak bu sürecin ölçülmesinde de yine soyut kuralların öğrenciler tarafından bilinip bilinmediğini test eden ölçme araçları kullanılmaktadır. Geleneksel olan bu teknikler ise dilin kullanımı mümkün kılmamaktadır. Bu bağlamda bu çalışmanın amacı Almanca dilbilgisi derslerinde etkili bir ölçme ve değerlendirme yapabilmek için kullanılan ölçme araçlarının hangi özelliklere sahip olması gerektiği, ölçme aracı hazırlarken soruların nitelikleri, yapısı ve amaca hizmet etmesi için hangi özelliklere sahip olması gerektiğine ilişkin önerilerde bulunmaktır. Literatür taraması yapıldığında genel anlamda yabancı dil öğretimine özel anlamda dilbilgisi öğretimine ilişkin ölçme 
ve değerlendirme konusunda çok az sayıda araştırmaya rastlanmıştır (Bkz. Altmışdört 2010; Cinkara 2017; Deniz/ Dinçel 2015). Dolayısıyla bu çalışmanın alternatif ölçme ve değerlendirme teknikleri konusunda alana katkı sağlaması beklenmektedir.

\section{Alternatif Ölçme ve Değerlendirme}

Eğitimde ölçme ve değerlendirme işlemi geleneksel ve alternatif tekniklerle olmak üzere iki biçimde yapılabilmektedir. Doğru yanlış, eşleştirme, boşluk doldurma soruları, kısa ve uzun cevaplı yazılı yoklamalar geleneksel ölçme ve değerlendirme teknikleri olarak değerlendirilirken; performans değerlendirme, ürün seçki dosyası (portfolyo), kavram haritaları, proje, drama, görüşme, yazılı raporlar, gösteri, poster, grup veya akran değerlendirmesi, kendi kendini değerlendirme, kelime ilişkilendirme testleri alternatif ölçme ve değerlendirme teknikleri olarak sınıflandırılmıştır (Meb 2007). Alternatif ölçme ve değerlendirme teknikleri geleneksel ölçme ve değerlendirmede olduğu gibi sadece sonuç odaklı değil; öğrenciyi merkeze alarak öğrencilerin öğrenme süreçlerini de değerlendirmesi bakımından daha verimlidir. Aşağıda alternatif ölçme ve değerlendirme teknikleri kısaca açıklanmıştır.

Alternatif ölçme ve değerlendirme tekniklerinden biri olan performans değerlendirme; öğrencilerin bilişsel, duyuşsal ve devinimsel becerilerini kullanarak bir ürün ortaya koymasıdır (Dağl1 2014: 51). Performans değerlendirmede öğrenci bir ürün ortaya koyabilmek için analiz etme, akıl yürütme, eleştirme ve sentezleme gibi üst düzey zihinsel becerileri kullanır. Şiir, öykü, kompozisyon vb. yazma performans değerlendirmeye örnek olarak verilebilir. Performans değerlendirmede öğrenci tarafından bir ürün ortaya konulduğu için geleneksel tekniklerdeki gibi öğretmen tarafından tek bir doğru cevap belirlenemez. Öğrencinin ürünü üzerinden belli ölçütler dikkate alınarak değerlendirme yapılabilir.

Diğer bir alternatif ölçme ve değerlendirme tekniği de kelime ilişkilendirme testleri tekniğidir. Bu teknikte ölçülmek istenen ve merkeze alınan bir anahtar kavramın veya yapının hatırlattığı diğer bütün kavramların ve yapıların cevap olarak yazılması istenir (Dağlı 2014: 49). Öğrencinin bilişsel şemasındaki yapılar arasındaki bağlantılar bu teknikle ortaya çıkarılabilir. Dolayısıyla bu teknikle işlevsel olarak birbiriyle bağlantılı olan konuların öğrenciler tarafindan bütüncül olarak görülmesi sağlanarak öğrenme kalıcı hale getirilir.

Ürün seçki dosyası (portfolyo); öğrencinin bir dönem boyunca öğretim sürecinde her bir performansının kaydedildiği, yine öğrencinin öğretim sürecinde baştan itibaren geçtiği aşamaların görülebildiği ve öğrencinin yaptığı bütün çalışmaları gösteren dosyadır (Dağlı 2014: 39). Bu teknikle öğretmen, her bir öğrencinin dönem boyunca gelişimini geleneksel ölçme ve değerlendirme tekniklerinde olduğu gibi sadece tek bir sınav kâğıdına bakarak değil; dönem boyunca birden fazla ürünü değerlendirmeye alarak öğrenci hakkında bir yargıda bulunabilir. Dolayısıyla bu şekilde hem öğretmen öğrencinin gelişimini; hem de öğrenci kendi gelişimini takip ederek daha güvenilir ölçümlerin yapılması sağlanmış olur. 
Kavram haritası; bir temel veya üst kavrama ilişkin bilgi ve düşüncelerin sınıflandırılarak kavramlar aralarında bağ kurulmasını sağlayan bir tekniktir (Altınok/ Açıkgöz 2006: 22). Bu teknikte birbiriyle ilişkili olan konular arasında sınıflandırma yapılarak öğrenme eksiklikleri saptanabilir.

Proje tekniği; öğrencilerin gerek bireysel gerekse de gruplar halinde bir konu veya probleme ilişkin kapsamlı araştırmalar sürdürerek ortaya çeşitli ürünleri çıkarmalarıdır (Sünbül 2011: 175). Bu teknikte öğrencilerin hem okul ortamında hem de okul dışı ortamlarda sürdürdüğü çalışmaları da değerlendirmeye alınarak öğrencilerin okul dışı ortamlarda da öğrenmeyi sürdürmeleri desteklenir. Projenin grup halinde yapılması ise öğrencilerin birbirlerini değerlendirmesini sağlayarak diğer bir alternatif ölçme ve değerlendirme tekniği olan akran değerlendirmesinin de kullanılmasına imkân verir.

Akran değerlendirme tekniği ise öğrencilerin birbirlerinin yaptıkları çalışmaları, ürünleri değerlendirmesidir (Dağlı 2014: 57). Bu teknikte öğrenme ve değerlendirme sorumluluğu sınıftaki diğer öğrencilere de verilerek başarılı olan veya beklenen düzeyde olmayan çalışmaların, öğretmenin dişında diğer öğrenciler tarafından incelenmesi ve değerlendirilmesi sağlanır. Bu teknikle başarılı olan çalışmalar, değerlendirme sürecine dâhil olan diğer öğrenciler tarafından örnek alınarak öğrencilerin öğrenme eksiklikleri de giderilmiş olur. Dolayısıyla öğrenme eksiklikleri olan öğrencilerin başarılı ürünleri görme imkânı elde etmelerine bağlı olarak eksikliklerine ilişkin farkındalıkları gelişerek öğrenme süreci de desteklenmiş olur.

Öz değerlendirme; öğrencinin öğrenmelerini ve performansını takip ederek kendi öğrenme süreciyle ilgili yargıda bulunmasıdır (McMillan 2015: 360). Bu teknikte öğrenci kendi öğrenme sorumluluğunu alarak ölçme ve değerlendirme süreci içerisinde yer alır.

Yazılı raporlar; öğrencilerin hedef kazanımları içeren bir olayı, durumu veya düşünceyi ev ödevi biçiminde raporlaştırmalarıdır (McMillan 2015: 294). Bu teknikte öğrenci yazılı olarak kendi ifade gücünü kullanarak hedef kazanımlara ilişkin bildiklerini ortaya çıkarabilir.

Diğer bir alternatif ölçme ve değerlendirme tekniği de dramadır. Drama, farklı disiplinlerde kullanıldığı gibi eğitimde de son dönemlerde gerek öğretim yöntemi olarak gerekse de ölçme ve değerlendirme tekniği olarak kullanılmaya başlanmıştır. "Eğitimde drama öğrencilerin kendilerini başkalarının yerine koyarak çok yönlü gelişmesi, öğretme-öğrenme sürecinde etkin rol almasıdır” (Sünbül 2011: 308). Buradaki amaç öğrencinin kendini rahat ifade edebileceği, öğrendiklerini kullanabileceği ortamların oluşturulmasıdır. Drama tekniği aracılığıyla öğrenci gerçek yaşam ortamlarını deneyimleme imkânı elde eder. Bu teknikle yaparak ve yaşayarak öğrenme ön planda olduğu için ölçme ve değerlendirme aşamasında uygulama düzeyinde bir ölçüm yapılmış olur. 


\section{Ölçme Aracında Bulunması Gereken Özellikler}

Ölçme işlemi, geleneksel öğretim anlayışında olduğu gibi öğrenciye sadece not vererek dersten geçtiğini veya kaldığını belirlemek amacıyla yapılmamalı; bunun yanında öğrenciye kendi öğrenme sürecine ilişkin bilgi verebilmek amacıyla da yapılmalıdır. Bu amaca ulaşabilmek için ölçme aracının belirli özelliklere ve niteliklere sahip olması gereklidir. Dolayısıyla ölçme işlemi aslında bilindiği gibi nicel bir süreçten ziyade nitel bir özellik de kazanmalıdır. $\mathrm{Bu}$ ise ölçme işlemine eğitbilimsel açıdan işlevsellik katarak gerçekleştirilebilir. $\mathrm{Bu}$ bağlamda ölçme aracının işlevleri şu şekilde açıklanabilir.

Ölçme aracı, öğrencilere öğrendiklerini pekiştirme olanağı vererek kalıcı öğrenmelerin gerçekleşmesine katkı sağlamalıdır. Bu özellikteki bir ölçme aracı ise öğrencilerin ölçme işlemine ilişkin algılarının değişmesini sağlayabilir. Genellikle öğrenciler sınavdan sonra sorumlu oldukları öğrenme girdisinin artık önemli olmadığını düşünürler. Çünkü artık sınav bitmiştir ve onlara göre bir daha bu hedef kazanımlar onların karşısına çıkmayacaktır. Bu olumsuz durumun önüne geçebilmek için ölçme aracındaki her bir soru türünün yapılandırmacı öğrenme yaklaşımına göre tasarlanan dersteki uygulama ve etkinlikleri kapsayacak özellikte olması gereklidir. Böylece öğrenciler ölçme işlemini öğretim etkinliği bittikten sonra eğitim ve öğretimin sonunda yapılan bir işlem olarak görmeyeceklerdir. Dolayısıyla ölçme işlemi yaparken de aslında nitelikli ve amaca hizmet eden soru türlerinin hazırlanarak öğrencilerin öğrenmelerine katkı sağlanabileceği düşünülmelidir.

Ölçme aracı öğrenmedeki eksikliklerin neler olduğuna ilişkin hem öğrencilere hem de öğretmenlere bilgi verici özellikte olmalıdır. Öğrenmedeki eksikliklerin ölçme aracıyla belirlenebilmesi için ise ölçme aracının kapsam geçerliğinin istenilen düzeyde olması önkoşuldur. Yani ölçme aracıyla öğretimin başında belirlenip öğretim sonunda ulaşılması hedeflenen bilgi ve beceriler ölçülebilir nitelikte olmalıdır.

Ölçme aracında bulunması gereken diğer bir özellik de ölçme aracının derste kullanılan yöntemin etkililiği hakkında öğretmene bilgi verebilmesidir. Ölçme ve değerlendirme sürecinden sonra öğrencilerin öğrenmelerine ilişkin elde edilen sonuçların beklenildiği gibi veya beklenenden daha düşük olması, derste kullanılan yöntemin; öğrencilerin ilgi, ihtiyaç, öğrenme stilleri ve öğrenme stratejilerine uygunluğu hakkında öğretmene bilgi verir. Ölçme aracının, öğretim sürecinde kullanılan etkinlik ve uygulamaların dışında ezber bilgiyi ölçmeye yönelik soru türleriyle tasarlanması, öğrencilerin derse ilişkin motivasyonlarının düşük olmasına da neden olabilir. Ölçme aracının öğrenme etkinlikleriyle paralel olması, öğrencilerin dersi önemsemesini sağlar. Dolayısıyla ölçme, öğretim süreci içerisinde yapıldı̆̆ı için öğretim sürecini destekler ve öğrencilerin ilgi ve motivasyonları üzerinde etkili olur.

Ölçme işleminin önemli bir işlevi de öğrencilerin yanlış öğrendiklerinin tespit edilmesini sağlayarak hataların düzeltilmesine firsat vermesidir. Bu özellikte hazırlanan bir ölçme aracı dönüt-düzeltme işlevine sahip olarak öğrencilerin eksik bilgilerini tamamlamasını sağlar. Genel olarak ölçme aracı öğretim hedeflerine uygun soru türlerine sahip olacak nitelikte olmalıdır. 


\section{Almanca Dilbilgisi Öğretiminde Ölçme ve Değerlendirme}

Günümüzde yabancı dil öğretiminde dilbilgisi öğretimi odaklı yaklaşım yerine iletişimsel yeti yaklaşımı yani iletişimsel yabancı dil öğretimi kabul edilmiştir (LarsenFreeman 2000). Yabancı dil derslerinin iletişim kurmaya yönelik yürütülmesi düşüncesini savunan iletişimsel yaklaşım, günlük hayatta yabancı dilde iletişim kurmak için gerekli olan bilgi ve bunların kullanılması için gerekli olan becerilere sahip olmak anlamına gelmektedir (Aktaş 2005; Kurtz 2013). Bu yaklaşımda da savunulduğu gibi yabancı dil derslerindeki öğrenme girdilerinin günlük dil kullanımlarında, iletişim ortamlarında aktif bir biçimde kullanılması, yabancı dil derslerinin asıl amacıdır. Bu durum Almanca dilbilgisi derslerinde öğretilen kural ve kavramların öğretiminde de geçerlidir. Çünkü Türkiye'de Almanca dilbilgisi derslerinde yoğun bir dilbilgisi öğretimi söz konusudur. Dilbilgisi konu ve terimleri öğretilirken öğrencilerin söz konusu yapıları günlük hayatlarında, iş ortamlarında, resmi yazışmalarda, sosyal etkileşimlerde ve bunlara benzer daha birçok ortamda kullanmaya ihtiyaç duyup duymadıkları dikkate alınmadan, yabancı dil olarak Almancanın yapısal bütün özellikleri yapay bir öğrenme alanı olan okullarda aktarılmaktadır. Alan yazında geleneksel dilbilgisi olarak nitelendirilen bu süreçte tümevarım yöntemiyle dilin biçimsel özelikleri, terim, sözcük ve cümle öğretimi üzerine yoğunlaşılarak dilin, içerikten uzak soyut kavram öğretimi ön plana çıkarılmaktadır (Demircan 2012; Demirel 2004; Klotz 1996). Geleneksel dilbilgisinde dilin biçimsel özellikleri betimlenerek dilin nasıl kullanılacağı, işlevsel özellikleri açıklanmaz; bu nedenle geleneksel dilbilgisinde öğretilen yapılar günlük dil kullanımlarında ihtiyaç duyulan yapılar ile örtüşmez. Kuralların öğrenciler tarafından ezberlenmesi veya ezbere bilinmesi hedef davranış olarak belirlenir (Steinig/ Huneke 2010: 111). Hedef davranışların ezbere dayalı olarak belirlenmesi ise ölçme ve değerlendirme sürecinde hazırlanan ölçme aracının niteliğine de etki etmektedir. Dilbilgisi derslerinde genellikle boşluk doldurma, ilk örnek cümle verilerek diğer soruların verilen örnek cümleye göre yapılması gibi sorular hazırlanmaktadır. Dilbilgisi derslerinde kuralların öğretimine öncelik verilmesine bağlı olarak ölçme ve değerlendirme süreci de dilbilgisinin biçimsel yönünün öğrenciler tarafından kazanılıp kazanılmadığına odaklanmaktadır. Geleneksel öğretim yaklaşımıyla yürütülen Almanca dilbilgisi derslerinin sınavlarında boşluk doldurma, doğru yanlış soruları, yapıyı tamamlama, eşleştirme şeklinde teknikler kullanılmaktadır. Dolayısıyla ölçme araçları hazırlanırken dilbilgisel yapıların kullanımı ölçülmemekte, öğrencilerin biçimsel olarak dili tanıyıp tanımadıkları ölçülmektedir. Görüldüğü gibi ölçme araçlarındaki yapı geçerliliği sadece dilin şekilsel yönünün tespit edilmesine bağlı olarak yapılmaktadır. Bu durum ise yabancı dil öğretiminde dilbilgisi öğretiminin amaçlarıyla örtüşmemektedir. Çünkü dilbilgisi öğretimindeki temel amaç, dilin salt içerikten soyutlanmış kurallarını öğretmek değil; öğrencilerin seviyelerine bağlı olarak öğrencilere okuma, dinleme, konuşma ve yazma becerilerini kazandırmak ve onların etkili bir şekilde dili kullanmalarını sağlamaktır (Göçer 2015: 233). Bu bağlamda iletişimsel yeti yaklaşımı dikkate alınarak tasarlanmış bir dersin ölçme aracı da öğrencilerin dili kullanmalarını sağlayacak nitelikte olan ölçme ve değerlendirme teknikleriyle hazırlanmasını gerektirir. Yukarıda da açıklandığ 1 gibi geleneksel dilbilgisi 
derslerinde dilin yapısal özelliğinin (biçimsel yapısı) ön plana çıkarılarak işlev yönünün (dilin kullanımı) ihmal edilmesi durumu ölçme aracına da yansımaktadır. Şöyle ki dilbilgisi dersleri için kullanılan ölçme araçlarında dilbilgisinin biçimsel yönü ölçülmekte işlevsel yönü eksik bırakılmaktadır. Bu durum ise ölçme aracının kapsam geçerliliğinin düşük olmasına neden olmaktadır. Kapsam geçerliliği; bir ölçme aracının öğretim programında belirlenen hedef kazanımların ve ölçülmek istenen özelliklerin tamamının ölçme işlemine dâhil edilmesidir. Ölçme işlemini yapan kişinin ölçülmesi gereken kazanımların bazılarına ölçme aracında çok fazla yer verip diğerlerini ölçme dışında bırakması durumunda ölçme aracının kapsam geçerliği düşük olur (Dağlı 2014: 69). Bu durumda ölçme aracının amaca hizmet etmede yetersiz kaldığı söylenebilir. Bu nedenle dilbilgisi öğretiminde ölçme aracının amaca yönelik olması, öğrenciler hakkında ayrıntılı değerlendirmede bulunarak doğru sonuçlara ulaşmada belirleyici olmaktadir.

\section{Almanca Dilbilgisi Dersinde Ölçme Aracı}

Almanca dilbilgisi dersindeki ölçme araçları genel olarak ezbere dayalı olan boşluk doldurma, eksik bırakılan yapıyı veya cümleyi tamamlama, dilbilgisi kurallarını doğru eşleştirme gibi soru türlerinden oluşturulmaktadır. $\mathrm{Bu}$ nedenle öğrenciler de ezberledikleri takdirde yapabilecekleri bu tür sorulara yönelik olarak bir çalışma sistemi uygulamaktadırlar. Bunu yaparken de dilin kullanımını önemsemeyerek yabancı dilin biçimsel boyutuna yoğunlaşmaktadırlar. Bu düşünceyi destekler nitelikte Parmaksız ve Yanpar (2006) da alternatif değerlendirme yaklaşımlarının kullanılabilirliğine ilişkin yaptıkları çalışmada öğretmenlerin en fazla klasik ölçme araçlarını kullandıkları, alternatif ölçme araçlarını hiçbir zaman kullanmadıkları sonucuna ulaşmışlardır. Geleneksel öğretim yöntemlerinin ön planda olduğu öğretim ortamlarında tercih edilen klasik ölçme araçları ise yapılandırıcı öğretim anlayışının amaçlarına ulaşmada yeterli olmamaktadır. Buna bağlı olarak öğretim sürecinde doğru ve güvenilir değerlendirme yapmak için çeşitli ve birden fazla ölçme araçları kullanılmalıdır. Çünkü "geleneksel araçların ölçemediği özellikleri ölçmede alternatif araçları da tercih etmek eğitim sürecinin kalitesini artırmada etkili olacaktır" (Karakuş 2013: 17). Nasıl ki yapılandırmacı yaklaşıma uygun olarak düzenlenmiş öğretim ortamlarında bireysel farklılıklara bağlı olarak her öğrenciye ulaşmak için çeşitli yöntem ve teknik kullanılmakta ise, ölçme ve değerlendirme sürecinde de öğrencilerin duyuşsal, bilişsel, bireysel eğilimlerinin farklılığ 1 göz önünde bulundurularak çeşitli alternatif ölçme ve değerlendirme araçları tercih edilmelidir. Bunlar yukarıda da belirtildiği gibi öğrenci seçki dosyasındaki etkinliklerin değerlendirmesi, akran değerlendirme gibi alternatif ölçme ve değerlendirme teknikleri olabilir. Örneğin sınav kaygısı ve fobisi olan öğrenciler klasik sınav ortamlarında kendilerini, sahip oldukları bilgi ve becerilerini ifade etmede zorluk yaşamaktadırlar. Bu türde bir engeli olan öğrenciler ise alternatif ölçme araçları kullanılarak sınav kaygısının olmadığı daha rahat bir ortamda yaptığı bir ürün veya performans değerlendirmesiyle ölçme ve değerlendirme süreçleri iyileştirilebilir. Böylece ölçme ve değerlendirme sürecine dâhil olan olumsuz dişsal faktörler de devre dışı bırakılmış olur. Çünkü "hedef kitlenin dil kazanımlarına erişim 
düzeyinin belirlenmesinde birkaç ölçme aracı ve yönteminin birlikte işe koşulması ve çoklu değerlendirme araçlarının kullanılması doğru ve güvenilir sonuçlar almak bakımından yerinde olacaktır” (Barın/ Başar 2016: 47). Öğrenci ürün dosyaları, öz değerlendirme, akran değerlendirme, öğretmen gözlemleri, çalışma yaprakları, kontrol listeleri gibi alternatif ölçme araçlarının kullanımının ise birçok olumlu etkisi söz konusudur. Öğretim elemanlarının üniversite düzeyinde kullanabilecekleri alternatif ölçme ve değerlendirme yöntemlerine ilişkin görüşlerinin araştırıldığı bir çalışmada öğretim elemanları alternatif ölçme ve değerlendirme tekniklerinin öğrencilerin derse yönelik ilgilerini arttırdığg, öğrencilerin ders dışında da dil öğrenimine zaman ayırmak istediklerini belirtmişlerdir (Dönder ve diğerleri 2012: 960). Yukarıda belirtilen öğrenci ürünleri gibi alternatif ölçme araçlarının öğretime katkılarının yanında ölçme aracından öncelikle beklenen; ölçme aracının dersin kazanımlarını, öğrenme çıktılarını ve sınıf içerisinde yapılan etkinlikleri yansıtmasıdır. Canale ve Swain'a (1980) göre bir ölçme aracının geçerliliği hakkında bir değerlendirme yapmak için öncelikle ölçme aracının hangi hedef kitleye uygulandığına dikkat etmek; bunun yanında ölçme aracının hedef kitlenin öğretim sürecindeki öğrenme etkinliklerine, becerilere, öğrenme çıktılarına paralel bir özellikte olması gerekmektedir (Akt. Aydın ve diğerleri 2016: 3).

"Ölçme ve değerlendirme ölçülmek istenilen amaca, alana göre farklı ölçme araçlarıyla yapılabilir” (Deniz/ Keray Dinçel 2015: 17). Bu bağlamda Almanca dilbilgisi öğretiminde de dilbilgisi dersinin amacına uygun nitelikte ölçme aracı kullanılmalıdır. Çünkü yabancı dil öğrenim sürecinde dilbilgisi öğretimindeki amaç, dilin kullanımını sağlayarak dilin biçimsel özelliklerinden ziyade yabancı dilin aslında kendisini öğretmektir. MEB'in yabanc1 dil öğretim yönetmeliğinde belirtildiği gibi yabancı dil öğretiminin amacı, bireyin yabancı dilde dinleme, konuşma, okuma ve yazma becerilerini kazanmasını sağlayarak beceri odaklı bir yaklaşımın (Meb 2006) benimsenmesine bağlı olarak ölçme süreci de buna uygun olarak yapılmalıdır. Krashen ve Terrel'e göre ölçme araçları öğrencilerin öğrenmelerini ve dil gelişimlerini geliştirmeye yönelik olmalıdır (1983; Akt. Altmışdört 2010: 176). Dolayısıyla dilbilgisi dersinde de salt kuralların öğretimi yerine; öğrencilerin dil becerilerini geliştirmeye hizmet eden öğrenme ortamlarının hazırlanması gereklidir. Dil becerilerini geliştirici öğrenme ortamlarının hazırlanması ise işlevsel dilbilgisini ön plana çıkarmaktadır. Bilindiği gibi işlevsel dilbilgisi derslerinde etkinlik ve uygulama merkezli bir ders anlatımı yapıldığı gibi bu sürecin ölçülmesi amacıyla tasarlanan ölçme araçlarında da etkinliklere ve uygulamalara yönelik soru türlerine yer verilmelidir. Yabancı dil öğretimi dil becerileri, dilin yapıları, sözcük bilgisi vb. olmak üzere çok boyutlu bir süreç (Altmışdört 2010: 176) olduğu için bu sürecin bütüncül değerlendirilmesi önemli bir husustur. Ölçme durumları ayrık ve bütüncül nitelikte de yapılabilir. Ayrık nitelikli ölçmelerde her bir soru tek bir bilgi veya beceriyi ölçerken; bütüncül ölçmelerde ise öğrencilerin ölçme aracındaki soruları cevaplayabilmesi için birden fazla becerisini de bir arada kullanması gerekmektedir (Cinkara 2017: 126-127). Böylece dilbilgisi öğretimi kavramsal boyuttan çıkıp üretimsel bir nitelik kazanabilmektedir. Çünkü dil öğretimi üretimsel boyutta yapıldığı sürece başarı elde edilebilir. Dolayısıyla ölçme araçlarının da bu dilsel üretimi ölçmeye dayalı hazırlanması ölçme aracına işlevsellik 
kazandırabilmektedir. Dilbilgisi dersleri yapılırken okuma, yazma, konuşma dersleriyle ilişkilendirme yapıldığı takdirde dilbilgisi soyut yapıların öğretildiği bir ders olmaktan çıkıp daha işlevsel ve pragmatik bir değer kazanabilir. Bu durumun tam tersi de yapılmalıdır. Şöyle ki okuma ve yazma derslerinde de soyut kavramların okuma ve yazma becerileriyle nasıl hayata geçirilebileceği, bu yapıların kullanımı da açıklanmalıdır. Dolayısıyla ayrıştırılmış bir dilbilgisi dersi yerine ilişkilendirilmiş bir ders düzeneği tasarlanmalı ve uygulanmalıdır. Almanca öğretiminde dilin yapısal özelliklerinin öğretildiği dilbilgisi derslerinin ayrı bir ders olarak işlenmesi bu dersin diğer derslerden bağımsız bir ders olduğu anlamına gelmemelidir. Dilbilgisi, beceri edinimi için bir araç olarak kabul edilmelidir. Çünkü Cinkara'ya göre bireyin dil becerilerine sahip olması demek, bir amaç doğrultusunda bireyin dili kullanabilme yeteneğine sahip olması anlamına gelmektedir (2017: 124).

Ölçme araçlarının özellikleri ve etkileri öğrencilerin sınava yani derse ilişkin algılarını da belirleyerek öğrencilerin öğrenme sürecine olumlu veya olumsuz biçimde etki etmektedir. (Green 2007; Akt. Cinkara 2017: 131). Dolayısıyla dilin kullanım düzeyini ölçmede yetersiz olan eşleştirme, boşluk doldurma gibi mekanik sorularla hazırlanan geleneksel ölçme araçları, öğrencilerin bu tür soruları cevaplayabilecek bir çalışma sistemi geliştirmelerine neden olmaktadır. $\mathrm{Bu}$ durum ise öğrencilerin dil becerilerinin gelişimini olumsuz etkileyecektir. Ancak bunun tersi bir durumda; yani öğrencilere dilin kullanımını destekleyecek sorularla oluşturulan ölçme araçlarının sunulması, onların sınava hazırlanırken ezberden kaçınmalarını, dilsel yapının işlevini kavrayarak söz konusu dilsel yapıyı kullanacakları biçimde bir tutum sergilemelerini sağlayacaktır. Türkiye'deki eğitim sisteminin sınav odaklı şekillendirilmesi de göz önünde bulundurulduğunda bu durum daha da önem kazanmaktadır.

\section{Almanca Dilbilgisi Dersinde Alternatif Ölçme Araçlarının Kullanımı}

Yukarıda da açıklandığı gibi Almanca dilbilgisi dersinde boşluk doldurma, eksik cümleyi tamamlama, doğru ve yanlış gibi geleneksel tekniklerle oluşturulan ölçme araçlarının geçerliği; ölçülmesi gereken bilgi ve becerileri ölçmede yetersiz kaldığı için düşük olacaktır. Bunun yanında geleneksel ölçme teknikleri ile bilgi düzeyinde bir ölçme işlemi yapılmış olur. Bu durum ise işlevsel dilbilgisinin temelinde olan dilsel yapıların ve kuralların uygulamaya dönüştürülmesiyle örtüşmemektedir. Bloom taksonomisinde öğrenme sürecinde belirlenen bilişsel hedefler karmaşıklık düzeyine göre basamaklandırılmıştır. Bloom taksonomisi bilgi, kavrama, analiz, uygulama, sentez ve değerlendirme olmak üzere altı basamaktan oluşmaktadır. Her basamak bir önceki basamaktan daha fazla zihinsel beceri gerektirmektedir (Bloom 1972). Örneğin öğrencinin ezberlediği bir bilgiyi kendisinden bir şey katmadan geri vermesi bilgi düzeyindeki bir kazanımı belirlerken; edindiği bilgiyi aktif bir biçimde kullanması ise uygulama düzeyine karşılık gelmektedir. Bu bağlamda işlevsel dilbilgisinin amaçlarına uygun olarak tasarlanan ölçme araçları oluşturulurken hedef davranışların Bloom'un taksonomisindeki bilgi düzeyinin değil; kavrama, analiz ve uygulama gibi düzeylerin dikkate alınmasının doğru ve güvenilir ölçme ve değerlendirmenin yapılması noktasında 
önemli olduğu söylenebilir. Tasarlanan ölçme araçlarıyla ölçülmek istenen hedef kazanım bilgi düzeyinde bir hedef kazanımı değil; uygulama, analiz ve değerlendirme gibi üst düzey kazanımları ölçmek amacıyla hazırlanmalıdır. $\mathrm{Bu}$ yolla dilbilgisi konularının öğrenciler tarafından uygulandığı ürünlerin oluşturulmasına olanak veren alternatif ölçme ve değerlendirme tekniklerinden olan performans değerlendirme, ürün ve seçki dosyası, kelime ilişkilendirme testleri gibi tekniklerle öğrencilerin sadece Almanca dilbilgisine ilişkin kuralları ve yapıları öğrenip öğrenmediği ölçülmekle kalınmaz, bu kuralları içselleştirip mekanikleştirerek uygulayıp uygulamadıkları da ölçülmüş olur. Böylece hem kısmi hem de bütüncül değerlendirme yapılmış olur. Bu nedenle zorluk derecesine göre basitten zora doğru basamaklandırılan öğrenme hedeflerinin ölçülmesi de alternatif ölçme ve değerlendirme teknikleri ile yapılmalıdır. Yani ölçme araçları öğretim sürecinde kullanılan etkinlik ve uygulamaları da kapsayarak aslında sadece ölçme ve değerlendirme işlevinde değil; aynı zamanda öğrencilerin öğrenmelerini de destekler nitelikte olmalıdır. Bu amaca ulaşmak için ise “öğretmen mümkün olduğu kadar farklı ölçme araçları kullanmalıdır. Öğretmenlerin çoğunluğu boşluk tamamlamalı, çoktan seçmeli, eşleştirmeli, kısa cevaplı soru tiplerini kullanmaktadırlar" (Kırmızı 2009: 50). Öğretmenlerin çoğunun kullandığı çoktan seçmeli, eşleştirmeli ve boşluk doldurma türü gibi geleneksel ölçme araçlarındaki sorular bilgi düzeyindeki hedef kazanımları ölçerken; kavrama, analiz ve uygulama gibi üst düzey bir zihinsel bilgi ve becerileri ölçmede yeterli olmamaktadır.

Almanca dilbilgisi öğretiminde performans değerlendirme, ürün seçki dosyası, kavram haritaları, proje, drama, görüşme, yazılı raporlar, gösteri, poster, grup veya akran değerlendirmesi, kendi kendini değerlendirme, kelime ilişkilendirme testleri gibi alternatif ölçme araçlarının kullanılması ise hem sonuç hem de süreç odaklı bir ölçme ve değerlendirmeyi gerektirir. Yani burada öğrencinin sadece sınavlardan aldiğı nota bakılarak bir değerlendirme yapılmaz; öğretim sürecinde öğrencilerin birden fazla zihinsel süreç becerilerini kullanarak meydana getirdikleri ürünler de değerlendirmeye alınır. Ölçme araçlarının farklı olması, ölçme ve değerlendirmeye verilen sürenin de farklılaşmasına neden olmaktadır. Boşluk doldurma türündeki sorulara verilen süre ile metin, şiir yazma gibi sorulara verilen süre aynı değildir. Dilbilgisindeki hedef kazanımların dil becerileriyle birlikte bütünsel olarak ölçülmesi için öğrencilerin dilbilgisi konularını kullanarak oluşturduğu ürünlerin ölçülmesine imkân veren üretime dayalı teknikler tercih edilmelidir. Bu bağlamda alternatif ölçme ve değerlendirme tekniklerinin Almanca dilbilgisi dersine uyarlanarak kullanılmasına ilişkin öneriler aşağıda açıklanmıştır.

Almancada sifatlar konusu, yapısal olarak anadildeki veya İngilizcedeki sıfatlardan farklı bir özelliğe sahiptir. Belirli ve belirsiz tanımlık kullanımına ve ismin durumuna göre cümle içerisinde tanımlık ve sıfatlar farklı farklı yapılara dönüşmektedir. $\mathrm{Bu}$ durum ise ilişkisel olarak bütün farklı kullanımların ölçülmesini gerektirmektedir. Dolayısıyla sıfatlar konusunun ilişkisel olarak, bütün farklı durumlarının bütüncül biçimde ölçülmesi amacına ulaşabilmek için ölçme aracı olarak kavram haritaları kullanılabilir. Alternatif ölçme ve değerlendirme tekniklerinden kavram haritaları; genel bir üst kavram altında kavramların birbirleriyle bağlantılarını 
gösteren bir şemadır. Bilginin zihinde canlanarak bütüncül görülmesini sağlar (Köksal 2017: 149). Yine Almancada sıfatlar konusunun öğrenciler tarafından işlevsel olarak kullanılıp kullanılmadığını ölçebilmek için performans değerlendirme tekniği kullanılabilir. Burada geliştirilen ölçme aracında görsellerden yararlanılarak öğrencilerin betimleme yapmaları, sahip olmayı istedikleri bir nesneyi veya hayranlık duydukları birini tasvir etmeleri istenebilir. Böylece öğrencilerin ölçme işlemi aracılığıyla soyut yapılara işlevsellik kazandırabilme düzeyleri ölçülmüş olur.

Diğer bir alternatif ölçme ve değerlendirme tekniği de yazılı raporlardır. Bu teknik özellikle zamanlar konusunun ölçülmesi amacıyla tercih edilebilir. Örneğin "Partizip Perfekt" (dili geçmiş zaman) veya "Präteritum" (şimdiki zamanın hikâyesi) konularının öğrenciler tarafından kullanılma düzeyini ölçmek için katıldıkları bir etkinliği veya kendileri için unutulmaz anılarının olduğu bir günü rapor etmeleri istenebilir.

Bilindiği gibi Almancada edilgen anlam başta "werden+Partizip Perfekt" ile olmak üzere 12 farklı yapı ile verilebilir (Balcı 2009: 64-65). Bunlar arasındaki yapısal benzerlik ve farklılıklar kelime ilişkilendirme testleri tekniği kullanılarak ortaya çıkarılabilir. Örneğin "man-Konstruktion” (edilgen özne) ile “werden+Partizip Perfekt" (edilgen yapı) arasındaki anlamsal yakınlık ise kelime ilişkilendirme testleri tekniği kullanılarak ortaya çıkarılabilir. Dolayısıyla bu teknik ile öğrencinin farklı yapıların, yakın ya da aynı anlamda kullanıldığını bilip bilmediği ölçülmüş olur. Bunun yanı sıra bu teknikte ilişkilendirme yapıldığı için sadece ölçme ve değerlendirme işlemi yapılmayıp öğrenme süreci de desteklenmiş olur. Kelime ilişkilendirme tekniği "Relativpronomen" (ilgi zamiri) ve "Partizip I" (sıfat-fiil) yapılarının ölçülmesinde de tercih edilebilir. Relativpronomen ve Partizip I konuları yapısal olarak farklı olmalarına rağmen anlamsal olarak birbirlerinin yerine kullanıldıkları durumlar mevcuttur. Örneğin "der Mann, der kommt, ist mein Vater" cümlesi ile "der kommende Mann ist mein Vater" cümlesinin bu teknikle ilişkilendirilmesi sağlanabilir. Konular arasındaki anlamsal yakınlığa göre konular birbirine ne kadar yakın ve ilişkili ise öğrenci o derece mevcut bilgileri arasında bağlantı kurabilir (Dağlı 2014: 50).

Dilek ve şart kipinin ölçülmesinde performans değerlendirme tekniği kullanılabilir. Bu teknikte yukarıda da belirtildiği gibi öykü, kompozisyon ve şiir yazma görevleri öğrencilere verilebilir. Dilek ve şart kipinin işlevine göre edebi bir tür olan şiir tercih edilebilir. Bu bağlamda öğrencilerden özlem duydukları bir kişi veya nesneye yönelik istek ve dileklerini ifade ettikleri bir şiir yazmaları istenebilir. Böylelikle öğrencilerin hem biçimsel hem de işlevsel olarak dilek kipini kullanma düzeyi ölçülmüş olur. Yine bu konu için alternatif ölçme ve değerlendirme araçlarından olan gösteri tekniği kullanılabilir. Gösteri bir gruba teknolojik aletlerin kullanılarak bir davranışın, işin nasıl olduğunu göstermek ya da bir ilkeyi, bir beceriyi açıklamak için başvurulan bir tekniktir (Köksal 2017: 196). Örneğin bir film izletilerek o filmde geçen dilbilgisi yapılarını bulmaları istenebilir. Film ölçülmek istenen dilbilgisel yapılar dikkate alınıp farklı farklı filmlerden kolaj yapılarak ölçme aracı olarak kullanılabilir. Ancak bu tekniğin kullanılması için okuldaki teknolojik altyapının iyi düzeyde olması 
gerekliliğinin yanı sıra öğretmenin de daha fazla zaman harcaması ve emek vermesi kaçınılmazdır.

Almanca dilbilgisi dersinde ölçme araçları oluşturulurken kullanımsal, kurgusal, özgün, metinler, diyaloglar, şarkı, fabl, hikâye, gazete ilanları, yemek tarifleri, davetiyeler, kullanım kılavuzları, reklam metinleri ölçme aracı biçiminde düzenlenerek ürün seçki dosyası tekniğiyle birlikte kullanılabilir. Burada tercih edilen metinler ölçme tekniğine hizmet eden materyallerdir. Örneğin günlük hayatta öğrencinin duyduğu şarkıdaki dilbilgisi konuları vurgulanıp şarkının nakaratı verilerek öğrencinin gerisini hayal gücünü de kullanarak kendine göre tamamlaması istenebilir. Daha sonra öğrencinin ortaya çıkardığı ürünü, ürün seçki dosyasına alınarak değerlendirilir. Çocuk ve gençlik edebiyatındaki yazın dilinin daha sade ve anlaşılır olması nedeniyle dil öğretiminde bu türlerden de yararlanılabilir. Dolayısıyla çocuk, gençlik edebiyatındaki yazınsal metinler tercih edilen alternatif ölçme ve değerlendirme tekniğinde bir araç veya yardımcı materyal olarak kullanılabilir.

Alternatif ölçme ve değerlendirme tekniklerinden biri de gözlemlerdir. Öğretmen ders sürecinde öğrencilerin öğrenme süreçlerine yönelik gözlem yaparak değerlendirmede bulunabilir. Çünkü öğretmen gözlemleri de birer ölçme aracı olarak öğrencilerin değerlendirilmesinde önemli bir rol üstlenebilir. "Bilimsel süreç becerilerinden biri olan gözlem, uzun bir zaman dilimini kapsar ve öğrencilerin eğitimöğretim sürecindeki gelişimlerinin öğretmen tarafından takibini gerektirir" (Altunbay 2017: 402). Dolayısıyla gerek ders anlatım aşamasında gerekse de etkinlik aşamalarında öğretmen; ürünlerini oluşturma süreçlerinde öğrencileri takip ederek neleri yapıp neleri yapamadıklarını gözlemleyip öğrenciler hakkında bir değerlendirmede bulunabilir. Bu durum ise süreç değerlendirmesine örnek olarak verilebilir.

Almanca dilbilgisinin ölçme ve değerlendirme sürecinde öğrenciye kendi öğrenme sürecine yönelik yargıda bulunma olanağı veren öz değerlendirme tekniği de kullanılabilir. Öğrenci dönemin başından itibaren derste yapılan etkinliklerle meydana getirdiği ürünleri değerlendirerek kendi dilsel gelişimi hakkında yargıda bulunup öz değerlendirme sürecine dâhil edilir ve bu yöntemle kendisini öğretmenin yaptığ değerlendirmeyle kıyaslama olanağı elde edebilir. Öz değerlendirmenin güvenirliğini sağlamak amacıyla da öğretmen yardımıyla öz değerlendirme formları hazırlanmalıdır. Dolayısıyla değerlendirme sürecini desteklemek için öğrenci ürün dosyaları oluşturularak sürece ilişkin öğrencilerin kendilerini değerlendirmesi de desteklenmelidir. Çünkü öğrencilerin hangi bilgi ve becerilere sahip olduğunu, neleri öğrendiğini ve neleri uygulayabildiğini bilmesi öğrencilerin kendilerine güven duymasını sağlar (Özbay 2009: 157). Öğretmen gözlemlerinin ve öğrenci öz değerlendirmelerinin kullanılması ölçme ve değerlendirme sürecinin sadece klasik ölçme araçlarıyla yapılmasının önüne geçerek bu süreci tek boyutlu olmaktan kurtarır. Yukarıda önerilen alternatif ölçme araçlarının tasarlanmasında kullanılabilecek sorularla öğrencilerin üretimsel olarak ölçme ve değerlendirme sürecine dâhil olmaları sağlanır. Ölçme ve değerlendirmeyle aynı zamanda öğrencilerin öğrenmelerinin devam ettirilerek bu sürece katkı sağlanması amaçlanmaktadır. Bu nedenle buradaki amaç sadece not vermek değildir. 
Alternatif ölçme araçlarının geliştirilmesi ise öğretmene daha fazla iş yükü oluşmasına neden olmaktadır. Çünkü kısa cevaplı boşluk doldurma türü soruları okumak ve değerlendirmek, performans değerlendirme ve kavram haritaları gibi ürüne yönelik bir değerlendirme yapmaktan daha kolaydır. Örneğin yazılan bir metni değerlendirirken değerlendirme anahtarı, ölçütleri, rubrik oluşturulması gerekir. $\mathrm{Bu}$ ise öğretmen açısından düşünüldüğünde daha fazla emek ve iş yükü anlamına gelir.

Eğitim fakültelerinin Almanca öğretmenliği programlarında EBB kodlu eğitim bilimleri temel alanı kapsamında ölçme ve değerlendirme dersi yer almaktadır. Bu derste özel alan uzmanlığı gözetmeksizin genel olarak ölçme ve değerlendirmeye ilişkin temel kavramlar öğretilmektedir. Derste her alanın içerik ve öğrenme kazanımlarının farklılık göstermesine bağlı olarak özel alana yönelik ölçme aracı tasarım nitelikleri açıklanamamaktadır. Dolayısıyla bu derse işlevsellik kazandırmak amacıyla Almanca öğretmenliği programı için Almanca öğretiminde nasıl bir ölçme aracı geliştirilmesi gerektiğine ilişkin özel alan bilgisiyle harmanlaştırılmış bir ölçme ve değerlendirme dersi önerilebilir. Yani öğretmenler kendi özel alanlarının gerektirdiği ölçüde ölçme ve değerlendirmeye dair bilgi ve becerilere sahip olmalıdır. Öğretmen adaylarının ölçme ve değerlendirme alanına ilişkin yeterlik algılarının araştırıldığı bir çalışmada öğretmen adaylarının ölçme ve değerlendirmeye yönelik algılarının yüksek olmadığı belirlenerek, bunun nedeni ise ölçme ve değerlendirme konusunda yeterli eğitimi almamaları, derslere alan uzmanlarının girmemeleri gösterilmiştir (Yaman/ Karamustafaoğlu 2011). Bunun yanı sıra ölçme ve değerlendirmeye ilişkin yapılan bazı çalışmalarda öğretmenlerin alternatif ölçme araçlarını hazırlamada kendilerini yeterli görmedikleri belirlenmiştir (Anıl/ Acar 2008; Çakan 2004; Yaman 2011).

\section{Sonuç}

Öğretim sürecinin planlanıp uygulanması kadar bu süreç hakkında bilgi veren ölçme ve değerlendirme aşaması da öğretimi etkileyen önemli bir aşamadır. Ölçme sürecinde kullanılan ölçme araçlarının ölçülmek istenilen davranışı ölçme gücü ise ölçme aracının kapsam geçerliliği ile açıklanabilir. Dolayısıyla bir ölçme aracında öncelikle bir öğretim programında öğrenciye kazandırılması hedeflenen bilgi ve becerilerin ölçülebilir olması bu bağlamda çok önemlidir. Bu durum Almanca dilbilgisinin öğretim hedefleri için de geçerlidir. Yabancı dilin amacının öğrenciye yabancı dilde iletişim becerisinin kazandırılması olmasına bağlı olarak ölçme araçlarının da boşluk doldurma, eşleştirme türü tekniklerle değil; öğrenci ürün dosyaları, öz değerlendirme, akran değerlendirme, öğretmen gözlemleri, çalışma yaprakları, kontrol listeleri gibi öğrencinin dili kullanma düzeyini belirleyici tekniklerle hazırlanması önemli bir husustur. Bu çalışmada da öğrencilerin sadece sınavlardan aldığ 1 nota bakılarak bir değerlendirme yapılmaması gerektiği; öğretim sürecinde öğrencilerin birden fazla zihinsel süreç becerilerini kullanarak meydana getirdikleri ürünleri ortaya koyabileceği alternatif ölçme ve değerlendirme teknikleriyle ölçme ve değerlendirmenin yapılmasının hem güvenilir ölçme ve değerlendirme sürecine hem de öğretim sürecine katk1 sağlayacağ1 vurgulanmıştır. Almanca dilbilgisi derslerinde ölçme araçları oluşturulurken 
kullanımsal, kurgusal ve özgün metinler, diyaloglar, şark1, fabl, hikâye, gazete ilanları, yemek tarifleri, davetiyeler, kullanım kılavuzları, reklam metinleri alternatif ölçme ve değerlendirme tekniklerinde materyal biçiminde düzenlenebilir. Bunun yanı sıra kavram haritaları, performans değerlendirme, ürün seçki dosyası, proje, drama, görüşme, yazılı raporlar, gösteri, öğretmen gözlemleri, öğrenci öz değerlendirmeleri de alternatif ölçme ve değerlendirme teknikleri olarak sürece dâhil edilmelidir. Buradaki amaç ölçme araçlarında mümkün oldukça öğrencilerin dili kullanmalarına olanak verecek, aktif uygulamaya dönük tekniklerle dil becerilerinin desteklenmesidir.

Ölçme ve değerlendirme sürecinin geleneksel yaklaşımda benimsendiği gibi öğrenciyle ilgili sadece yargıda bulunma işlevinin olmadığı; aynı zamanda öğrencinin öğrenme sürecine katkı sağlayacak nitelikte yapılması gerektiği belirtilmiştir. Öğrencilerin ölçme ve değerlendirme aşamasında da yeni öğrenmeler gerçekleşebilmektedir. Bu nedenle ölçme ve değerlendirme süreci öğretimin sonlandığ1 bir aşama olarak görülmemelidir. Böylece ölçme ve değerlendirme işlemi öğrencilerin duyuşsal ve bilişsel gelişimi üzerinde etkili olabilecektir. Çünkü ölçme ve değerlendirmenin iyi yapılması durumunda öğrencilerin derse karşı motivasyonları da artış gösterecektir. Yabanc1 dil öğretmenlerine ölçme ve değerlendirme, ölçme aracı geliştirme konusunda hizmet içi eğitim verilmelidir. Eğitim fakülteleri lisans programlarında yer alan ölçme ve değerlendirme dersine öğrencilere farklı ölçme ve değerlendirme araçları hazırlama firsatı verilmesi amacıyla teorik bilgilerin öğrencilere aktarıldığı ders saatinin yanında uygulamalı bir ders saati de konulmalıdır.

\section{Kaynakça}

Aktaş, Tahsin (2005): Yabanc1 Dil Öğretiminde İletişimsel Yeti. Selçuk Üniversitesi Sosyal Bilimler Enstitüsü Dergisi, 12.45-57.

Altınok, Hülya/ Açıkgöz, Ü. Kamile (2006): İşbirlikli ve Bireysel Kavram Haritalamanın Fen Bilgisi Dersine Yönelik Tutum Üzerindeki Etkileri. Hacettepe Üniversitesi Ĕgitim Fakültesi Dergisi, 30. 21-29.

Altmışdört, Gonca (2010): Yabancı Dil Öğretiminde Nasıl Bir Ölçme - Değerlendirmeye Gerek Vardır. Kuramsal Eğitimbilim, 3. 175-200.

Altunbay, Müzeyyen (2017): İlköğretimdeki Yabancı Dil Derslerinin Yöntem ve Ölçme Değerlendirme Yönünden Karşılaştırılması. 1st International Black Sea Conference on Language and Language Education, September 22-23. Ondokuz Mayis University, Samsun. 396-404.

Anıl, Duygu/ Acar, Meltem (2008): Sınıf Öğretmenlerinin Ölçme Değerlendirme Sürecinde Karşlaş̧ıkları Sorunlara İlişkin Görüşleri. Yüzüncü Yll Üniversitesi Eğitim Fakültesi Dergisi, 5. 44-61.

Aydın, Belgin vd.(2016): Türkiye'deki Hazırlık Okullarının Yeterlik Sınavı Uygulamaları ve Bilgisayarlı Dil Ölçme Fikrine Yaklaşımları. Anadolu Üniversitesi Sosyal Bilimler Dergisi, 16. 1-20.

Balc, Tahir (2009): Grundzüge der Türkisch - Deutschen Kontrastiven Grammatik. Adana: Ulusoy Matbaas1.

Barın, Erol/ Başar, Umut (2016): Yabancı Dil Olarak Türkçe Öğretiminde Ölçme Değerlendirme Süreci: Türkçe Yeterlik Sınavı (TYS) İran Örneği. Route Educational and Social Science Journal, 3. 45-56. 
Bloom, Benjamin Samuel (1972): Taxonomie von Lernzielen im kognitiven Bereich, 16. Auflage. Weinheim und Basel: Beltz Verlag,

Cinkara, Emrah (2017): Dil Öğretiminde Ölçme ve Değerlendirme, Farklı Yönleriyle Yabancı Dil Ö̆gretimi, (Ed. Yılmaz, H.; Yücel E.; Durak Üğüten, S; Şanal, F.), Konya: Çizgi Kitabevi.

Çakan, Mehtap (2004): Öğretmenlerin Ölçme Değerlendirme Uygulamaları ve Yeterlik Düzeyleri: İlk ve Ortaöğretim. Ankara Üniversitesi Eğitim Bilimleri Fakültesi Dergisi, 37. 99-114.

Dağlı, Süleyman (2014): Ölçme ve Değerlendirme, e-kitap, yayıncı: www.gelecekrehberi.net. Erişim tarihi: 03.01. 2020.

Deniz, Kemalettin/ Keray Dinçel, Betül (2015): Anlama Becerilerine Yönelik Ölçme ve Değerlendirme Araştırmalarının İncelenmesi. Mustafa Kemal Üniversitesi Sosyal Bilimler Enstitüsü Dergisi, 12 (2015).16-46.

Demircan, Ömer (2012): Yabancı Dil Öğretim Yöntemleri, 5. Baskı, İstanbul: Der yayınları.

Demirel, Özcan (2004): Yabancı Dil Öğretimi, 2. Bask1- Ankara: Pegem A Yayıncılık.

Dönder, Ayşenur vd. (2012): Öğretim Elemanlarının Üniversite Düzeyindeki Temel İngilizce Öğretiminde Kullanılabilecek Tamamlayıcı Ölçme ve Değerlendirme Yöntemlerine İlişkin Görüşleri. Turkish Studies, 7. 953-968.

Göçer, Ali (2015): Temel dil becerilerinin geliştirilmesinde dil bilgisi öğrenme alanının yeri, işlevi ve öğretimi: bütünlük ilkesi ve tümevarım yöntemi ekseninde tematik bir yaklaşım. Eğitim ve Öğretim Araştırmaları Dergisi, 4. 233-242.

Karakuş, Baki (2013): Üniversite Yabancı Dil Hazırlık Sınıflarında Uygulanan Modüler Sistemdeki Ölçme ve Değerlendirme. Ĕgitim ve Öğretim Araştırmaları Dergisi, 2. 15-22.

Kırmızı, Bülent (2009): Anadolu Liselerindeki Almanca Dersinde Yer Alan Dilbilgisi Konularının Öğretiminde Karşılaşılan Sorunlar. Pamukkale Üniversitesi Eğitim Fakültesi Dergisi, 26. 42-53.

Krashen,Stephen/ Teller, Tracy (1983): The Natural Approach. Oxford: Pergamon Press.

McMillan, James H. (2015): Sınıf Iç̧i Değerlendirme, Etkili Ölçütlere Dayalı Etkili Bir Öğretim İçin İlke ve Uygulamalar. (Çev. Ed. Asım Ar1), 6. Baskı, Konya: Eğitim Yayınevi.

Milli Eğitim Bakanlığı (2006). Milli Eğitim Bakanlığı Yabancı Dil Ĕ̆itimi ve Öğretimi Yönetmeliği, erişim adresi: http://mevzuat.meb.gov.tr/dosyalar/424.pdf, erişim tarihi: 16.02.2020.

Milli Ĕgitim Bakanlığı (2007). Program Geliştirme ve Ölçme Değerlendirme Birimi. Ankara, erişim adresi:http://talimterbiye.mebnet.net/program-gel-birimi/olc-deg-birimi.htm, erişim tarihi 15.05.2020.

Özbay, Murat (2009): Özel Öğretim Yöntemleri 2. Ankara: Öncü Yayınevi.

Klotz, Peter (1996): Grammatische Wege zur Textgestaltungskompetenz. Theorie und Empirie. Tübingen: Niemeyer Verlag.

Köksal, Onur (2017): Öğretim İlke ve Yöntemleri Çă̆daş Uygulamalarla Yöntem ve Teknikler. 3. Bask1, Konya: Eğitim yayınevi

Kurtz, Jürgen (2013): Der Kommunikative Ansatz und seine Bedeutung für die Theorie und Praxis des Fremdsprachenunterrichts zu Beginn des 21. Jahrhunderts. FLUL Fremdsprachen Lehren und Lernen, 42. 80-93.

Larsen-Freeman, Diane (2000): Techniques and Principles in Language Teaching. Oxford: Oxford University Press.

Parmaksız, Ramazan Şükrü/ Yanpar, Tuğba (2006): Alternatif Değerlendirme Yaklaşımlarının Sosyal Bilgiler Öğretiminde Kullanılabilirliği. Fırat Üniversitesi Sosyal Bilimler Dergisi, 16. 159-172. 
Steinig, Wolfgang/ Huneke, Hans - Werner (2010): Deutsch als Fremdsprache, Eine Einführung 34, 5B. Berlin: Erich Schmidt Verlag.

Sünbül, Ali. Murat (2011): Öğretim İlke ve Yöntemleri, 5. Bask1, Konya: Eğitim Akademi.

Yaman, Süleyman/ Karamustafaoğlu, Sevilay (2011): Öğretmen Adaylarının Ölçme ve Değerlendirme Alanına Yönelik Yeterlik Algı Düzeylerinin İncelenmesi. Ankara Üniversitesi Eğitim Bilimleri Fakültesi Dergisi, 44. 53-72.

Yaman, Süleyman (2011): Öğretmenlerin Fen ve Teknoloji Dersinde Ölçme ve Değerlendirme Uygulamalarına Yönelik Algıları. İlkögrretim Online, 10. 244-256. 